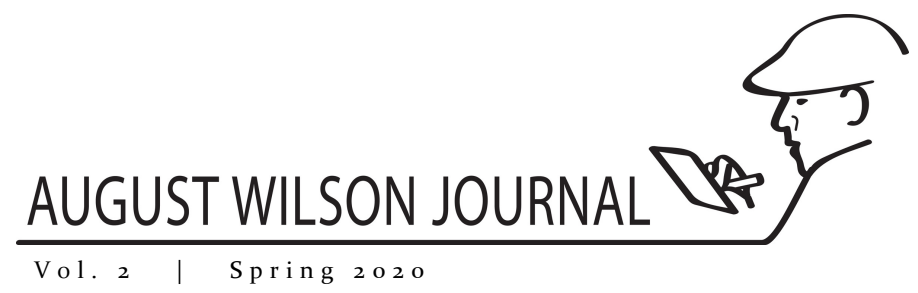

\title{
Stage Review of Jitney at Arena Stage
}

\author{
Kreeger Theater; Washington, D.C. \\ September 13-October 27, 2019
}

Directed by Ruben Santiago-Hudson

By Jacqueline Goldfinger

A playwright herself, the author teaches playwriting and dramaturgy at Temple University

"We provide a service to the community. We ain't just giving rides to people."

- Becker, Jitney

\begin{abstract}
A review of Jitney by August Wilson, staged at The Kreeger Theater's Arena Stage in Washington, D.C. from September 13 through October 27, 2019.

Keywords

August Wilson, Jitney, Ruben Santiago-Hudson, Arena Stage, Kreeger Theater, Hill District
\end{abstract}

In Ruben Santiago-Hudson's funny and heartbreaking production of Jitney at Arena Stage (as part of a national tour), Wilson's classic simmers with tension while illuminating the complex bonds of kinship that grow from decades of sharing a cramped work space. The jitney station where the men work is located in Pittsburgh's Hill District, a black neighborhood that's been slowly pushed to the brink of desolation by whiter and wealthier encroaching forces. However, the drivers stay. Their work is a Calling; they don't just deliver groceries; they deliver friendship, food, and care. They are the bulwark of a community ignored by public transit authorities and paid too little to afford individual cars. If the American Dream is all about speeding down Highway 66 to your house with a picket fence, it is the Hill District's jitney drivers that keep this Dream in service for their urban neighborhood. The mundane tasks like driving someone to and from the grocery store seem perfunctory on the surface-especially to a

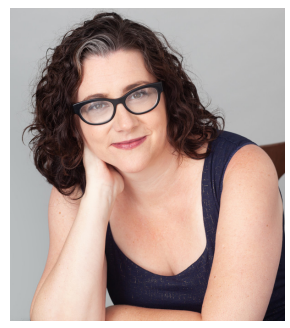

Jacqueline Goldfinger contemporary generation that is used to summoning a Lyft at the touch of a button. However, driving people across the span of decades, means that you share in their life, their successes and their defeats every day. Their shared situation in the District and their need of one another to attend to daily life has blossomed into unique intimate relationships with 
drivers dedicated to certain riders, and riders to drivers. These relationships have been complicated, as have the drivers' lives, by external forces like gentrification and internal forces like a stagnant local business community that has not kept up with the times.

While steeped in American Black culture of the 1970s, the production resonated deeply with a wide swath of the country that is experiencing removal from their homes and splintering of their communities for the "greater good" today. Whether forced to relocate due to gentrification, the building of a highway system, or other such project, the American capitalist tradition of ripping communities apart in the name of "progress"-which is often coded language for "wealthier people want to be here now"-is alive and well. This stark reality gives the national tour of Jitney a dual purpose of both entertaining and reminding us of the stories of real people behind the headlines of urban renewal. Santiago-Hudson's choice to steep us in the vivid emotional life of the characters rather than strenuously favor the social and political themes, honors Wilson's legacy of People First Theater.

Wilson had significant statements to make on society, culture, and the American experience, yet he always prioritized the full humanity of his characters over bullhorn-andbanner declarations-and Santiago-Hudson deftly maintains this tradition. For example, while there was a window in the jitney station that provided a cloudy view of the outside world, the heart of the station - the couch and chairs where the community gathers to sit and talk-were center stage. In addition, Becker's desk, the emblem of the "business" of the station, was pushed into a deep corner, so that the couch, chairs and drivers had ample room to stretch, breathe, and talk. The external elements were literally pushed aside, to make room for the emotional and spiritual ones. In addition, Santiago-Hudson directed his actors to lean into the conversations revolving around both personal relationships and how the personal relationships are being shaped by outside forces, like the downward spiraling economy of the neighborhood. But all straight business talk was delivered quickly, occasionally almost as an aside, consistently directing attention back to the humanity of the story, rather than the political and economic histrionics. While the outside forces exerting pressure on the jitney station were clear, the hearts and souls of the characters were center stage.

Santiago-Hudson's superb production, anchored by the steadfast Becker, played with a gorgeous fragility and daunting grace by Steven Anthony Jones, capitalizes on the keen and well-observed humor of Wilson's play. For example, in Becker's strained relationship with his son, no matter how tense, Jones always managed to find a point of connection, often in a moment of humor, that reminded of us of the hope and love that has been overrun by dusty layers of contention, but that still might fully surface one day. There was a "hope against hope" mentally deftly underlying Jones' performance. This stroke of genius helped us-an audience removed from those events in Pittsburgh's Hill District by 50 years-to connect deeply with the characters early on through laughter and the ineffably recognizable bonds of family even if the surroundings and slang are unfamiliar. As we synced with the heartbeat of Wilson's characters-played by a brilliant ensemble cast-the production maintained the important specificity of a Black American Urban Experience but also cracked open wider questions that we all connect with regarding ownership, definitions of home, and how the disruption of displaced communities has negative reverberations throughout society with a net negative for us all-despite the elusive promises of "greater goods" to come.

Often well-meaning productions, when dealing with difficult subjects that inspire revolt, become diatribes for or against a subject. Thankfully, Santiago-Hudson's production did not fall into that trap. David Gallo's smart set design made immediately clear that the focus of the play's story was the people, not the outside world swirling around them. Once the play began, the actors electrified the room. By freeing the actors from the long-standing American theatrical convention of trying to make every word of dialogue clear and understood, the director and performers thoughtfully overlapped dialogue and brought a rhythm to a piece which-much like opera--demands to be felt and understood beyond the 
intellect. While plot and character turning points were made clear, and sometimes underlined with careful staging, other moments in the play were allowed to ebb and flow over and around one another, creating an organically moving entirety that was magnetic and invited audience members to lean in and feel the waves of Wilson's sea crashing around them. Keith Randolph Smith (Doub) and Nija Okoro (Rena) were especially deft at finding moments of fully felt silence within this sea, allowing audiences a brief respite from Wilson's operatic flow of language for a moment to catch their breaths and before diving back into the waves.

\section{Works Cited}

Wilson, August. Jitney. The August Wilson Century Cycle. Theatre Communications Group. 2007.

\section{Author Bio}

Jacqueline Goldfinger is a playwright and dramaturg. She teaches MFA Playwriting and Dramaturgy at Temple University in Philadelphia. She also founded and runs Page By Page, a theater makers resource that shares playmaking tools around the country with an emphasis on increasing playwriting in underserved communities. 